\title{
Style and the New Poetic Revolution in Niyi Osundare's Poetry
}

\author{
Alu, Nesther Nachafiya
}

\begin{abstract}
The emergence of Niyi Osundare along with a new poetic revolution is perhaps the high point of the contingencies of the transition of Modern African/Nigerian poetry from the loins of Euro-Modernist Poetry. The transformative encounters of the first and second generations of Nigerian poets left behind patches of conflicting ideas. This paper is set against this background to explicate the poet's new poetic innovations within the framework of the Alter-Native Poetic Tradition. The synthesis of Western and African/Yoruba oral literary techniques are apparently laudable landmarks of the contexts. The adaptation of local language and traditional speech pattern are distinguishing features of this poetry. This paper, therefore, seeks to assess Niyi Osundare's poetic style, in the glare of the rising quest and need for an effective way of communicating Africa's poetic vision and African realities.
\end{abstract}

\section{Introduction}

Niyi Osundare who has made a name as a linguist, a critic and an experienced journalist and teacher is a poet devoted to serve the exploited African peasantry. He appears impressive and prominent among the younger generation of Nigerian poets. His works vividly convey his concept on the relationship between the oppressed Nigerian/African and the crop of leaders there. His works address a deluge of themes which include corruption, poverty, administrative mismanagement, and to a certain extent, the lingering effects of colonialism on the African continent. Literary artists of Osundare's school are engaged in the pursuit of social transformation by which their works challenge corruption and dictatorships, whether military or civilian, among other social vices. In line with this, Ekpa (1990) asserts that writers are becoming "freedom seekers, prophets, the voices of the people." 
The poet played a very prominent role in the campaign against the practices of the first generation of Nigerian poets often referred to as "Euro-Modernist poets" who tended to have lingered too long on the burden of managing the imperial lords' legacy or what Inyabri, Thomas (2006) calls "domineering images". Osundare also pioneered the team of critics who redefined and re-oriented a new trend in modern African poetry popularly tagged "Alter-Native Tradition in African Poetry." According to Chinweizu et al (1980) the Euromodernist African poets produced poetry which tended to be craggy, "limpy", full of obstructions which is apparently artificially difficult rendering simple ideas in esoteric idioms. These critics believe that the first generation of Nigerian writers' adaptation of Euro-Modernist Poetics was not only indiscriminate but dangerous to the development of traditional African flavour:

. . .an alien technique, based on an alien sensitivity that is rather too formalist ambiguity for ambiguity's sake, sprung rhythm for sprung rhythm's sake, etc obscure them as they try to present or explore thoughts that are rooted in the traditional African setting. (183)

The irrelevance of the older generation of Nigerian poets is undoubtedly the primary source of concern as identified by Chinweizu et al where they queried the undue "ambiguities, syntactical jugglery with suppression of auxiliary verb and articles, the spacious and contorted cadences of sprung rhythm, the heavy use of alliteration and assonance within a line..." (Chinweizu,1980). The pain as it is conveyed in Onyemachi Udumukwu (1999) has to do with the fact "... that their poetry is inaccessible in its ineffective attempts to imitate alien, particularly Western models." Chinweizu has fervently demonstrated that this penchant is manifest in the works of early poets like Okigbo, Soyinka, Echeruo and J.P Clark. Exemplary records of such are in poetry collections like Idanre and other poems (1969) and labyrinths (1971) by Soyinka and Okigbo respectively. 
Balami A. Shaffa,(1990) in Alu (1998) asserted that "basically, I believe that poetry is a song, and that the more beautiful a poem is the more versatile its effects are likely to be. A poem isn't just something scribbled; it is also something sung and chanted. I believe so much in the chant tradition."

The polemics on the over-indulgences of this first generation of Nigerian poets' with diverse records of euro-centric nuances led to what Thomas identifies as "willful obscurity", privatism, and abstractness. Apart from the evident cases of imitation and adaptation of the Modernist forms, there was what Funsho Aiyejina (1988) considers as far-fetched Graeco-Roman as well as Judo-Christian myths filled with "undue Eurocentricism, derivation, obscurantisms, and private orchestration" in the works of the troika, Soyinka, Okigbo and Clark. It was perhaps the prevalence of these features among other foreign imagery that made Aiyejina to raise an alarm that the nation's new realities that needed the poet's attention were ignored for what he termed "riddles and occult tongue" (Abdu 2003).

This problem led to ardent demands and open agitations for authentic African imagery, laments, invocations and the re-rooting of modern poetry in oral traditions. The emergence of the second generation of Nigerian poets, (namely Ojaide, Osundare, and Odia Ofeimun fully represented by their works which include Children of Iroko(1973), The Poet Lied (1980) and Songs of the Market Place (1983) came in to provide an answer. Most representative of this is Ojaide's statement in the poem 'Naked Words':

This is a family ceremony

to which the world has come,

If outsiders understand us

let them imbibe our wisdom and secrets

but we will not change our songs

because of their presence,

we will not sing their songs here

to show that we have heard them 
sing about themselves,

Let us not learn from teachers

who have no love for our land.

We must speak the truth

about ourselves to ourselves.

Without interpreters, middlemen.

Ojaide $\quad(1987: 11)$.

The battle of wits thus gradually plummeted into what Saleh Abdu calls "generational property- rights displayed at the battlefield of words" which apparently favour the new breed poets. This conflict is neither new nor strange in literary circles neither are reasons for such changes out of focus. Perhaps the closest precedence could be found in the centre stage of Bloomian paradigm which holds the notion that new or what is called "beginning poets" do establish their identities in a subtle combination of anxiety and influence." Harold Bloom adduces further that the influence of precursor poets or the strong poet, is a complex phenomenon. It produces an anxiety which fires the creativity of the strong poet as he moves to establish his own identity leading to his fame.

\section{Osundare as a Poetic Messiah}

Niyi Osundare is apparently one of the most outspoken of the new breed poets whose style marks him out as fitly messianic. Apparently a poet of substance, Osundare's attempt at addressing the problems facing critics and scholars of African poetry places him as an interesting look -alike of Bloomian "kenosis". He pioneers a campaign against obscurantism by dedicating Songs of the Market Place to propagate and celebrate what many critics came to believe was an over-asserted and unrealistic leap. The void, so seemingly created at kenosis in this context, gave Osundare the leverage to employ a befitting poetic medium to join the emerging new voices in poetry. The new breed poets principally sought to demystify it through the simplification of its language which Abdu Saleh affirms below: 
Osundare's poetic style marks him as a representative voice of the group. Through a studied critique and reworking of language of their predecessors, Osundare leads the group in their tacit task of liberating and demystifying the business of poetry to many readers. As language and language use lie in the essence of poetry, African poetry can only gain its distinctive voice quality by the degree to which its language-African or borrowed European- is shaped and reflected in local African experience (49).

Maduakor, another important voice in Nigerian poetry, however, believes that the new direction in the language of poetry has to do with the Nigerian civil war. The emergent style and the themes of their poetry tended to address the new socio-political and economic realities of the nation. He asserts that "a new attitude in language - the war revolutionized the attitude to language of Nigerian poetryimbued it with new energy, a new direction and a new urgency". (49). Olu Obafemi's observation that the poet's deployment of words as due to his "radical revolutionary vision" is also relative and reflective.

\section{Osundare's Language and Style}

The poet's interest in innovative style is conveyed in his ardent interest in the use of language. The avalanche of critical responses to Osundare's style, and the diverse conflicting stances, as well as the influencing factors of its brilliance, relevance and success in part necessitated this discourse. Attempt is thus made to sample some of the literary and oral devices the poet employs in a selection of his poems to make such observed impact.

Osundare sets out in Songs of the Marketplace to redefine poetry as "a life spring/which gathers timbre/ the more throats it plucks/harbingers of action /the more minds it stirs"(1). The poet rejects the earlier preconceived exclusive and obscure nature of African poetry. The poet quickly reworks the equation that amounts to African poetry, restating its nature, its dimension and acceptable 
medium as he emphasizes accessibility to its target audience. Apparently more reassuring and comforting to an erstwhile estranged audience, the poem poetry is illustrating this new posture:

\author{
Poetry is \\ No oracles kernel \\ For sole philosopher's stone \\ Poetry \\ Is \\ Man \\ Meaning \\ To \\ Man (1-2).
}

However, Osundare says his readers seem to have misunderstood his poem "poetry is". So he warns against oversimplifying the poem and ends up making it a yardstick of measuring the rest of his poems. He explains more succinctly that poetry is a "hawkers ditty/the eloquence of the gong/it is what the soft wind/music to the listening muse" (2). To ward-off some misconceptions Osundare explains that what the wind whispers could still be difficult after all:

I want you to distinguish between obscurity and difficulties, --- want you to distinguish between difficulties, obscurity and obscurantism. Anybody who expects that all poems should not be difficult does not understand what poetry is. Now anybody who expects all poems to be obscure doesn't understand what poetry is either... Alu (1998:99).

Although he admits saying poetry is "not the esoteric whispers of an excluding tongue," he opines that it does not mean, "Poetry is just out there---that you pluck a poem, put it on paper without working on it". The controversy could either contradict Osundare's stance, suggest a digression or both. The uncertainty of whether the advocated paradigm of the new breed poets is that transparent intellectual 
development, snobbery or truly bordering on Bloomian rivalry, establishes the relevance of Anna Balakian's (1985) submission that;

... the influences of authors of the same nationality and language upon each other are negative influences, the result of reactions, for generations often tend to rivals of each other and in the name of individualism reject in the work of their elders what they consider to be conventions of the past.

The triumph of Osundare's poetry and his new breed compatriots are most likely borne out of necessity rather than envy contrary to what Bloom's study reveals. The usual appellation poured on his use of domesticated language brings him close to the masses. It also makes his poems assume .... distinct anti-imperialist tone. This observation is subsequently crystallized in the famous essay by Funsho Aiyejina who asserts that Osundare being the most prolific of the lot, his poetry epitomizes the distinctiveness of the groups new style (Abdu 2003).

In the course of writing he has come to produce a blend of poetry that speaks for itself and that is quite independent and distinct from others poets even in the same category with him. The assertive differences of Songs of the Marketplace and Moonsongs give credence to this assertion. In the light of which he offers the following explanation in an earlier cited interview with Shaffa:

A poet who writes poems which don't require any energy, any spiritual and mental exercise to understand is not a poet, is a writer of doggerels. At the same time a poet who writes such poems that cannot be understood except by himself and one or two others is not a poet. He is a juggler, a magician. Alu (1998:100).

In the face of such ambiguity and contradiction some critics attribute it to struggle or Voice search which they feel has been found in The 
Eye of the Earth where he carries along into further experimental grounds as he seeks to transform his society. He has shifted from his initial political messages to emphasize poetic technique and formal experimentation:

The poet has abandoned the style of individual lyrics for a form of poetry in which a whole body of poems is organized around one or two motifs the poems evolving as stages of a single poem. The form has dominated the poems in Moonsongs and Waiting Laughters. (100).

In his poetry, we are confronted with many forces of oppression in the varying operative arenas. Most importantly, the feature of his poetry is his defense of the speechless and oppressed citizens of the land. He appears involved and sympathetic to their unfortunate condition, be it in the rural or urban area. The theme runs through all his collections, cutting across various fields of human endeavour. Affirming thus that he is essentially a politician, since a genuine poet has always been interested in politics which is a means of eradicating poverty, he opines:

And so when you have a country and a continent and a world where instead of that happening, politics is being used to entrench poverty and enrich a few, then problems are bound to rise. Poetry has become a tool for setting things right, for praising virtue... Genuine poetry raises political songs; political songs directly and indirectly. It tells kings about the corpses which line their way to the throne. It tells the rich ones the skulls in their cupboards. (100).

In Songs of the Marketplace, the poet dramatically depicts his concern with the socio-economic matters in contemporary Nigerian society, using fairly strong imagery which still leaves room for 
commitment, accessibility and expressiveness. Based partially on the said obsession with the plight of the underdogs, some critics associate him with socialist inclinations. This could be explained by the fact that he takes up the Marxian metaphor in describing the unnatural relationship between the rich and the poor; "the rich were not born so the poor need not die so..." Here are pictures of a society where the minorities live in affluence while the majorities swim in the pond of poverty.

Village Voices exposes the simplistic life style of the village dwellers juxtaposed to what obtains in modern urban civilization. The peasants who are the producers of food are diversely presented as wittysingers, jesters and satirists. Like Songs of the Marketplace, the central theme in both Village Voices and A Nib in the pond are the predicaments of the societal underdogs.

The Eye of the Earth is very special, fashioned on his perception of man in nature. The image of the poet here is more than an interpreter of a complex and rich tradition of his people who share a collective philosophy. He celebrates the work culture of his people with special emphasis on their reverence for nature, defending the traditional myth on which the community lives together resisting collision. The volume is seen as one of the fiercest indictments of modern economic culture of the people and alien destructive forces. It takes a pictorial account of aggression on man and the earth which is the author's personal contribution to the problems of erosion and desertification.

In Moonsongs, Osundare exhibits his commitment to socio-economic and political issues. He talks on the social malaise in the society. Phase XXII poem particularly handles the social disparity between the rich and the poor, reasoning that the seasons, just like life, always fluctuate, confirming in many of the poems in Moonsongs that life is transient. He addresses the mutability of seasons and the uncertainties of human conditions in Moonsongs reading meanings into life mainly from Yoruba oral folksongs. The lessons sink in as one begins to appreciate the medium of its actualization which is performance. The 
strength of the book as observed by most of its reviews lies more in its form than content, mainly because of the oral nature of its structure.

In Songs of the Marketplace, there are visible elements of genuine concern for this unfortunate part of the country's population , especially in poems like 'Excursion', 'Sule chase', 'Siren', 'At a University Congregation' and 'Reflection' to mention but a few. 'Excursion' is a fairly long poem which is a poetic irony for the journey he undertakes through different public places around, where life means different things to different people. Here, however, we are confronted with images of disease, poverty, deprivation and want which are symbolic pictorial portrayal of all facets of the Nigerian society.

In explicating thematic aspect of any work of art, the form of its existence is apparently of paramount importance; we are now ready to address his battle for a new poetic revolution in African poetry. This is why his poems exhibit features of African oral poetic style. The influences of various Yoruba oral genres such as the Oriki chant and Ijala hunter's song are very strong in collections like The Eye of the Earth and Moonsongs. Adebayo Babalola confirms the abundance of "Praise songs" in Yoruba tradition called "rara" Alu (1998). Perhaps for the purpose of musicality, the poet intentionally refuses to give the English versions of some of these direct borrowings from Yoruba language; "The moon, this night, is a rugged master. The moon, this night, is a rugged master / teregungun maja gungun tere ... (Emphasis added).

Direct address and dialogue are common features of oral styles extensively used in Osundare's works. In 'Publish and Perish', he is didactic and direct, with beautiful rhyming lines:

Tell me

Do you think they will accept this,

The A \& $\mathrm{P}$

Do you think they will? 
Just see

There are only a dozen references

footnotes don't wind across pages

"Tell me" and "just see" are both investigative and deductive in the way they are used in this poem. Looking bare of images, it is written in ordinary everyday English and very communicative. This looks more like newspaper captions or the traditional town crier's early morning message in times of war:

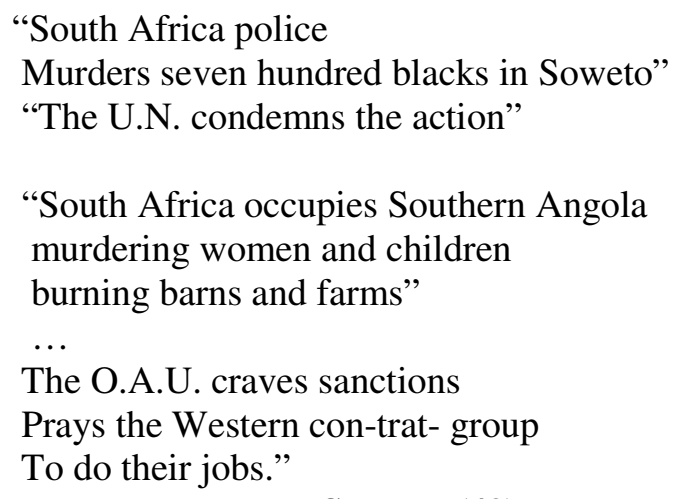

Songs...(49).

Investigative /direct address as a literary device is also used by the poet as used in Moonsongs:

Tell me, moon,

Where are your wrecks

Where are your wrinkles

Where, the creases left

On your wondrous robe ... (18).

Similarly, dramatic dialogue is effectively used by the poet as shown in Waiting Laughters:

Okerebu kerebu

Kerebu kerebu 
And the snake says to the toad

"I have not had a meal

for a good one week;

Any time my stomach yearns

For your juicy meat"

Suppose I turn into a mountain?

Asks the toad

"I will level you up in the valley

of my belly"...(63).

The much desired flavour of African authenticity in the works of the new poets is abundantly exploited by Osundare in Moonsongs. Perhaps that is why some scholars are of the view that to fully appreciate his wonderful craftsmanship in the book, one has to share, or at least have an insight into his Yoruba people's world view. The impact of Yoruba folk-song is very imminent revealing that the poet did compose with the native influence taking the upper hand.

Moonsongs is a collection of songs which Odugbemi observes “... is riveting lunacy of song... (Where) verses lap gently at the base of your soul... " (Word in bracket added) In a down to earth comment Odugbemi was quoted as saying:

The poet belts out his songs as though in a joy trance. He sweeps you from moonrise to moonset. Imagine yourself by the magic seas of a moonlit night lying on a carpet of songs, floating whimsically in the "soft windiness" of this night of the gods. Muyide, (39).

The opening song /poem which is performed to the accompaniment of war drumming, has its chorus interspersed with Yoruba. He is deeply rooted in his Yoruba oral tradition which, Saleh Abdu says, have formed the backbone of the poet's aesthetic-poetics:

Let the cricket slit night's silence

with the scapel of its throat

Let nightbirds coo and cuddle

In the swinging Eden of their nests; 
But when down finally climbs down

Through the leering rafters,

I will be a promise

Eternal like your seasonless sky

kiriji kiriji papelupe

\section{Moonsongs (2).}

He has exhibited and developed interest in oral performance poetry, which has thus emphasized public recitations, as well as written poetry with instruments for its orchestration. The rain songs, in the Eye of the Earth are highly lyrical and played in accompaniment of flute and rain drum:

Let it rain it today

That parched throats may heal her silence

Let it rain

The earth may heal her silence

Let it rain today

that corn leave may clothe the hills

Let it rain ... The Eye ... (28).

The poem also illustrates the use of repetitions of phrases, lines and structures to reinforce the lyrical tone of the songs employed in Waiting Laughters and Moonsongs:

And laughing heels so fugitive

In the just of fleeting truths

...

Truth of the sole

Truth of the palm

Truth of the liar

Truth of the lair (37).

The use of more than one literary device at a time is typical of Osundare as exhibited in these graphlogically deviant structures and repetitions. This type of literary device is used for emphasis to enhance meaning. I proscribe the snail/ I proscribe the shell/ I 
proscribe the frog/I proscribe the tadpole/ I proscribe the sea/ I proscribe the sky/ I proscribe the tale/ I proscribe truth. His punning devices are unique compound words used in Moonsongs as in "moonmares", "moonfire", "Moongrass", "Moonsweat", "Moonharvest", "mooncantations", "Mangoes", "hen hood" "our glass" "tale/tail" "toll/tale" and "seasun" which functions to enhance meaning as well as musicality.

The use of breath-space pauses, common in oral performances, is employed in Songs of the Marketplace; Moonsongs and Waiting laughters. This device takes care of punctuations in written English by the use of spacing in print as in 'Nightfall', 'Back to the future' and 'Phase XIII' poems. The structures of these breathing spaces usually result in some structural changes in the form of graph-logical deviations as shown below:

$\begin{array}{ll}\text { Some } & \text { say } \\ \text { You } & \text { moon } \\ \text { Are } & \text { the } \\ \text { Ash } & \text { es } \\ \text { Of } & \text { the } \\ \text { Sun } & \text { bath } \\ \text { Ing } & \text { limpid } \\ \text { Night } & \text { in } \\ \text { The } & \text { grey } \\ \text { Ing } & \text { of } \\ \text { Your } & \text { silence (23) }\end{array}$

More radical use of this device is clearly demonstrated in Waiting Laughters where he uses a letter of the alphabet as a line:

Long
er
than
the
$y$


a

W

$\mathrm{n}$

Moonsongs... (84)

Rhetorical questions are some of the devices used by the poet to produce the tempo in a number of poems especially as used below:

On moon oh moon where is your horse where, your hast Who reaped your gallop in the furrows of the sky.

Oh moon oh moon where is your wardrobe, where, your ward Who spread your silk in the loom of the sun.

Oh moon oh moon where is your udder, where, your pitcher

Who mothered the milk that bathes your limbs.

Oh moon oh moon where is your sage, where, your song Who carved the wood of your towering tree.

\section{Moonsongs (39)}

In phase IX poem, he further employs the device. This usage however is usually to build up pressure to buttress an idea. In this case to descend heavily on the selfish attitude of African leaders and the changing seasons respectively:

How many hours will make a minute

How many oceans total one drop

Of elusive water

How many forests will make one tree

In regions of meticulous showers

How many...? (17)

Other important elements of oral literature visibly utilized here includes, rhetoric's, proverbs, praise names, axioms and idiomatic expressions. This is the most popular device employed by African elders and community heads. This rich resource is illustrated in the following lines:

Ah! The peacock cannot count

Her century of feathers,

The parrot cannot count the chimes 
Which cat the bell of her restless beak.

\section{Moonsongs (17)}

Praise names are typical to African address system to elders or spiritual figures or gods. It is important to note here that there are traditional registers as there are the various English registers. Many African communities also share the use of wise sayings especially by community elders. The use of a cluster of wise sayings here are to buttress an idea of wasted labour:

Olosunta spoke first

The eloquent one

Whose mouth is the talking house of ivory

Olosunta spoke first

The riddling one whose belly is wrestling ground

For god and gold. The Eye... (13)

More interesting oral devices are employed on pages eighteen and nineteen:

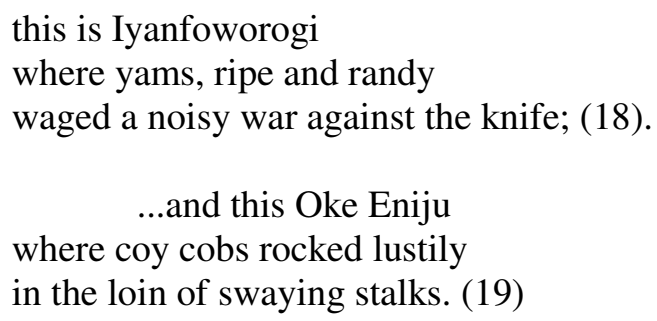

Osundare freely draws his embossed metaphor on the earth from the Yoruba Oriki and Ijala chants in which he applies an extended praisename to the Earth. This simply proves the fact that praise-name epithets are relevant and necessary features of public performance. These lines are illustrative of such special descriptions of the earth;

Temporary basement

And lasting roof

First clayey coyness 
And last alluvial joy

Breadbasket

And compost bed

Rocks and rivers

Muds and mountains

Ogeere Omokoyeri... The Eye (1)

After the African traditional usage, the poet weaves names to describe the nature and character of the earth. We also have praise- chants fashioned after Oriki praise chants of the Yoruba. In 'forest Echoes' the forest trees are given their praises according to their strength namely: the tough Iroko, "Oganwo" and feather weight "Ayunre". Oganwo, he declares;

... wears the surrogate crown

of heights and depths;

wounded by wanton matchets,

bled by the curing cutlass of the babalawo

the homing sun closes your weeping wounds

even as your doctor juice simmers,

in the portions at dusk. (6)

Such copious absorption of praise epithets by the poet are intended to make his poetry appeal to his local African audience. However, allusions are made to other literary devices that are commonly shared by the two literary traditions. Osundare has persistently made references to places, gods, persons and remarkable events in Africa in the creative process. In The Eye of the Earth for one, there are allusions to a rock in Ikere which the people of the town are said worship annually during "Olosunta festivals." He alludes to Olosunta a rock in the poem, 'The rocks rose to meet me', in which he personifies the rock and in five movements shower praises on it/him. He also does the same to Oroole, a pyramid shaped rock in Ikere 
which the poet describes as the 'pyramid of the brood' from where, the poet says, he could clearly see Amoye Grammar School.

In 'harvestcall' he celebrates the fertility of Iyanfoworogi, Oke-Eniju and Ogbese- Ode describing their life sustaining features. He likewise alludes to Okeruku" in 'meet me at Okeruku' as red earth district (33). These allusions highlight the poet's interest in his localized audience. The advantage of these physical landscapes in situating his audience in time and space enhances great sense of belonging and credibility.

Other features of oral traditions are grammatical parallelisms, similes, metaphors and noun/pronoun variations. Parallelisms can be either in the structure (syntax), or sound. In The Eye of the Earth, poems like 'Let earth's pain be soothed' 'Excursion' and 'What the Earth said', are illustrative of this device, which are variously structural, syntactical, rhythmical and repetitive such as:

let it rain today

that roots may swell the womb of lying plains

let it rain today

the stomachs may shun the rumble of thunder

let it rain

that children may bath and bawl and brawl (28)

In waiting laughters, parallelisms are extensively used, which critics opine is very important if the poet's experimental orchestration were anything to go by at all. He also needed refrains, preceding case or cases of structural and musical repetitions:

Waiting

for the heifer which bides its horns in the womb of the calf

Waiting

for the nail which springs an ivory wonder in the spotted arena of reading eyes 
Waiting...

Waiting

For fists which find their aim. (10).

In this type of parallelism, the lexical overlapping is apparent due to the repetition of phrases with their attendant grammatical variations. While these could sometimes be monotonous, particularly in written poetry, it is aesthetically strategic, especially when poems are read aloud. Other variations in style that could be placed between parallelism and juxtapositions are the effective employment of allusions which could be either situational or topical among others. Brilliant employment of socio-political incidents are recorded in Songs of the Marketplace where the poem 'Udoji' illustrates the use of topical allusions to the pay-hike Nigerian workers enjoyed in 1975 which is believed to have sparked off the raging inflation in the country. Similarly, Osundare's richest collection, The Eye of the Earth adeptly renders this rare employment of similes and metaphors in 'eyeful glances'. The remarkable thing about the employment of this subject is the manner of its delivery which is apparently grandiloquent:

The desert caller

Comes on a camel

Of clouds,

Undulates through the dunes

Of hazy shadows

$\&$

gliding through the open welcome

of January's door

whispers urgent tidings

in the ears of my skin. (23)

Poetic Epithets are literary devices usually indicative of formulaic language of oral poetry which help in the proper handling of the oral thought-process, 'forest Echoes' is illustrative of this poetic epithet:

Palm-bound, scalpel-toothed,

The squirrel pierces the tasty iris

Of stubborn nuts; 
Adze man of the forest,

Those who marvel the canine fire

In your mouth

Let them seek refuge in the fluffy grace

Of your restless tail. (8)

Musicality across monotonous rhythm is another prominent identifying feature of African poetic compositions which Sedar Senghor (as cited by Ojaide) says "is like inhaling and exhaling air". This musicality informs the poetic features of verbal, structural repetitions and parallelisms. Osundare has in his own special way imbibed what some critics called the "Agisymban" stylistic feature which is a characteristic of sound and drums, dancing feet and melody of tones as aptly employed in Waiting Laughters and Moonsongs hence reducing their complexity. It makes them more accessible to a larger audience of listeners and readers as in oral traditional performance. However, some of Osundare's texts, particularly Moonsongs, Eye of the Earth, and Waiting Laughters have come to prove that even though African oral devices are used, complexity is never really eliminated. This only leads to another stage of the debate on simplicity and complexity of the poetic language. The anatomy of these poems would reveal architectural manipulation of his medium as Saleh Abdu (2003) rightly observes:

...all the lexical, morphological and syntactic formations he employs to embody his impressions and assimilations of local-mostly oral-repertoire of the communication culture which he translates, transliterates or transposes into the English language.

\section{Conclusion}

The poetic innovations of Niyi Osundare seem to have split open the gridlock created by the pioneer Nigerian poets in their embattled Euro-Modernists innovations. Their popular and peculiar bout suddenly grew grungy. The glorious Eurocentric-privatist commune that distanced them from the commoners suddenly soured with the development of Africa's taste-bud, maturing critical perception, 
historical experience which characterized the prevailing realities of the time. The tenor and tone of his compositions are reasons for his diverse and sustained interests in his works. His swift moves filled the gap between what critics call "trivial-irrelevant and the relevantvibrant poetry traditions" The employment of rich Yoruba oral literary devices in his poetry made it unique and startlingly investigative. His people-centered approach is very central to the resolution of the polemics of governance and politics in art. (Abdu, 2003:20).

The relationship of the Soyinka-Clark-Okigbo group of poets and the Osundare-Alter-Native Tradition poetry, have been sharply contradicted, the one castigated, the other upheld. Although the later appear leftist and socialist in their ideological inclinations, they may still have imbibed some of the tenets Bloom represented in a complex "covering cherub" and "sphinx" relationship with its attendant complications. There are however affinities in the aspect he tags "intellectual revisionism" since it holds the notion that; "revisionism is a 'creative correction' of the works of the precursors which he asserts is beneficial because the "strong poet" deviates from "his poetic father(s)" insisting that they had got it wrong at that point of his deviation," thus the strong-emergent poet is observed to curve a niche for himself. Although Osundare and his compatriots have clearly curved a place not only for themselves but for the entire nation/Africa, it is not likely due to any rivalry of Bloomian kenosis.

Perhaps it is pertinent here to present Osundare's radical poetic style as clearly redefined concept and role. The sense of service to his African audience as exhibited by his rejection of Euro- Modernist models and what he calls "mysticisms/spiritual forces of African mythology" certainly frees him from Bloomian "influenza disease" which hinges on selfishness and rivalry. (Thomas, 2006:67). Purposeand responsibility rather than trivialities bear credence to Osundare's burden. To this fact, Abdu is a faithful witness:

Through a studied critique and reworking of the language of their predecessors, Osundare leads the group in their tacit task of liberating and 
demystifying the business of poetry for many readers. As language and language use lie at the essence of poetry. African poetry can only gain its distinctive quality by the degree to which its language -"African or borrowed European language" expression about being more African and less European has misguided. (19).

This confirms the error of those who discourage African linguistic and cultural experiences by placing more emphasis on African political ideology. Moreover, as Osundare's African linguistics and cultural concern partially endeared him to deploy such elements for the purpose of redefining and perfecting verse.

\section{References}

Abdu, Saleh, (2003) Poet of the Peoples Republic. Kano: Benchmark Publication.

Acholonu, k. (1993) "From Rhetoric's to Occultism: The Word as Music in the Poetry of Christopher Okigbo", African Literature Today; No 18.

Alu, N.A. (1998) Perspectives on Four African Poets. University of Jos. (Unpublished Ph.D Thesis)

Balakian, Anna (1985) Cited in Abdu Saleh, Poet of the Peoples Republic.

Aiyejina, Funsho, (1988) "Recent Nigerian Poetry." Perspectives in Nigerian Literature Ogunbiyi Ed.

Bamikunle, Aderemi (1993) "Niyi Osundare's Poetry and Yoruba Oral Artistic Traditon,"African Literature Today. No 18

Balami, H. Shaffa, (Interview with Osundare) "Poetry, Profession \& Philosophy of Life." Ibadan, 1 July 1990 Cited in N.A. Alu, Perspectives On Four African Poets. (unpublished).

Bloom, Harold (1973) The Anxiety of Influence: A Theory of Poetry. Oxford OUP 
Chinweizu et al (1980) Towards the Decolonization of African Literature.

Vol.1.1 Enugu: Fourth Dimension Publishers.

Ekpa (1990) 82-3 Cited in Saleh Abdu, Poet of Peoples' Republic

Elliot, Thomas Stern (1972) "Tradition and the Individual Talent." 20th

Century Literary Criticism: A Reader. London: Longman.

Inyabri, Thomas (2006) "Millennial Battle Ogaga Ifowodo and the Emergence of the third Generation of Nigeria Poets" Currents in African Literature and the English Language. Vol. IV, May, 67-76.

Ngara, Emmanuel (1990) Ideology and Form in African Poetry. London: Heinmann.

Odugbemi (1985) "Poetry for the People". Sunday Vanguard. February 10. Odumukwu, Onyemachi, (1999) "The Subject of the Nation in Osundare's Poetry” Abia Journal of Humanities, Vol. 1 No.1 June, 79-107.

Ofeimun, Odia (1980) The Poet Lied. London: Longman.

Ojaide, Tanure (1989)The Changing Voice of History: Contemporary African Poetry. Genere Afrique.

Osundare, Niyi (1983) Songs of the Marketplace. Ibadan: New Horn Press. (1984) Village Voices. London: Evans Brothers.

(1986) A Nib in the Pond. Ibadan: Heinmann, Nigeria. (1986) The Eye of the Earth. Ibadan: Heinemann, Nigeria.

(1988) Moonsongs. Ibadan: Spectrum Books. (1990) Waiting Laughters. Lagos: Malthouse Press Ltd

Maduakor (1986) Violence as Poetic Focus: Nigerian Poetry and the Biafran Experience" Nsukka Journal of Literature. No. 4.

Sallah, Tijjani (1984) New Poets of West Africa. Lagos: Malt house Press. Soyinka, Wole (1967) Idanre and Other Poems. London: Eyre Methuen. 